\title{
EVIDENCE-BASED MEDICINE AS PATIENT'S PROTECTION MEASURE IN JUDICIAL PRACTICE
}

DOI: 10.36740/WLek202012216

\author{
Volodymyr A. Zhuravel', Galina K. Avdeeva' ${ }^{2}$, Mykyta 0. Sokolenko² \\ ${ }^{1}$ NATIONAL ACADEMY OF LEGAL SCIENCES OF UKRAINE, KHARKIV, UKRAINE \\ ${ }^{2}$ RESEARCH INSTITUTE FOR THE STUDY OF CRIME PROBLEMS OF NATIONAL ACADEMY LEGAL SCIENCES OF UKRAINE, KHARKIV, UKRAINE
}

\begin{abstract}
The aim: To identify the role of evidence-based medicine, its principles and approaches to patients' rights protection and the provision of medical service optimization, the skills of medical staff improvement, increasing the objectivity of court decisions in cases of non-providing quality care or death.

Materials and methods: The authors used the decisions by the European Court of Human Rights (ECtHR) on the statements of victims of unprofessional actions by doctors, international and domestic regulations on patients' rights, statistics on the results of criminal proceedings on violations of patients' rights over the past 5 years, case law of criminal and civil jurisdiction in this category of cases, the results of surveys of prosecutors, as well as the results of research by scientists in the field of medical law and criminalistics. The research is carried out on the basis of a harmonious combination of philosophical approaches, general scientific and special methods of scientific knowledge, the complex of which is chosen taking into account the goals and objectives, object and subject of research.

Conclusions: In order to implement the patients' rights by legal means in accordance with the Convention for the Protection of Human Rights and Fundamental Freedoms, the European Charter of Patients' Rights and other international regulations in the field of medicine, the authors argue the need for greater implementation of evidence-based medicine into the practice of medical institutions as a means of improving the level of medical care and an obvious source of relevant information for litigation to protect the rights of patients and doctors. For patients' rights protection in the diagnosis and treatment of diseases, it is proposed to regulate a set of such measures: 1) to include in the educational programs of pharmacy and medicine such disciplines as «Evidence-Based Medicine» and «Rights of the patient and medical worker's rights»; 2) to oblige the doctor to explain to the patient or to his/her representative the differences of treatment protocols, to provide information to patients about official sources, which contain information on unified and updated treatment protocols and diagnosis of certain diseases, to obtain informed consent by the patient (his/her representative) on certain medical guideline; 3 ) to recognize medical guidelines as sources of law in criminal and civil proceedings as a kind of benchmarks for clarifying and assessing the facts of non-performance or improper performance of professional duties by a medical or pharmaceutical worker, violation of patients' rights, as well as means for doctors' legal protection and etc.
\end{abstract}

KEY WORDS: health care, patient's rights, medical law, clinical protocols, medical standards

Wiad Lek. 2020;73(12 p. II):2795-2803

\section{INTRODUCTION}

A few international health care legal acts have been adopted in recent decades, in particular: Universal Declaration of Human Rights; Convention for the Protection of Human Rights and Fundamental Freedoms; International Covenant on Civil and Political Rights; International Covenant on Economic, Social and Cultural Rights; European Social Charter (revised) (ETS N 163); Declaration of Lisbon on the Rights of the Patient, etc. Their norms are included in the legislation of many countries around the world, including Ukraine. Thus, some provisions of these regulations are contained in the Constitution of Ukraine, Civil, Family and Criminal Codes of Ukraine, laws of Ukraine "Grounds of Ukrainian legislation on health care», "On ensuring the sanitary and epidemiological well-being of population», «On the personal data protection», protocols, standards and other legal acts in the field of health care. Article 5 of the European Charter of Patients' Rights states that «Each individual has the right to freely choose from among different treatment procedures and providers on the basis of adequate information». The right to freedom of choice in health care is enshrined in the Civil Code of Ukraine (Part 2 of Article 284, Article 633), in the laws of Ukraine "Grounds of the legislation of Ukraine on health care» (clause «d» of Article 6, part 2 Article 34, Article 36, Article 38), «On Consumer's Rights Protection» (Article 21).

The right to consent to medical intervention and the right to refuse medical intervention are enshrined in Article 4 of the European Charter of Patients' Rights. Also, this right is enshrined in the Constitution of Ukraine (Part 3 of Article 28, Part 1 of Article 29), the Civil Code of Ukraine (Parts 3, 4, 5 of Article 284, Part 4 of Article 286, Article 289), Law of Ukraine "Grounds of the legislation of Ukraine on health care» (Articles 42, 43, 44).

In view of the above, it is important for Ukraine to actively take the necessary organizational and legal measures aimed at improving the quality of medical services, protecting the rights of patients from unprofessional actions by doctors, including by appealing to the courts. 


\section{THE AIM}

To show the advantages of evidence-based medicine, to argue the need for more active implementation in medical practice of unified and local clinical protocols developed and approved on the basis of evidence-based medicine and existing international standards, which should be considered in judicial practice as benchmarks to compare doctors' activities while providing medical care for the treatment of one or another disease. To identify factors that hinder or prevent the implementation of clinical protocols in medical practice as a means of realizing the patient's and doctor's right to a fair and effective justice. To assess the impact of the absence of such protocols on the objectivity of a court decision on non-provision or improper provision of medical care. To propose a set of measures that will help to the patients' rights protection.

\section{MATERIALS AND METHODS}

In order to achieve the objectives of the study, 25 judgments of the European Court of Human Rights on applications of victims of improper provision of professional duties by a medical or pharmaceutical worker, statistics on the results of criminal proceedings on violations of patients' rights over the past 5 years, the results of questionnaire of 128 prosecutors, 195 criminal court verdicts and 275 decisions and rulings by civil courts were analyzed. They were accessed through the official websites of the European Court of Human Rights (ECtHR) and the Judicial Administration of Ukraine. In particular, the decision of the European Court of Human Rights «Case of Arska v. Ukraine» of 5 December 2013 on application №45076/05 (violation of Article 2 of the Convention - inconsistency with the clinical protocols of doctors' actions to establish the patient's mental health and his/her ability to make decisions independently) [1]; decision on application № 4605/05 «Case of Petrova v. Latvia» of 24 June 2014 (violation of Article 8 of the Convention - transplantation of organs (kidneys and spleen) without the consent of the mother of the deceased in a traffic accident, his mother learned eight months after the death of her son about the fact of transplantation) [2]; decision on application №10060/07 «Case of Bataliny v. Russia» of 23 June 2015 (violation of Article 3 of the Convention - testing of a new medicinal product on a patient without one's consent) [3] and others.

In addition, international and Ukrainian legal acts were studied and analyzed (Universal Declaration of Human Rights, Convention for the Protection of Human Rights and Fundamental Freedoms, International Covenant on Civil and Political Rights, International Covenant on Economic, Social and Cultural Rights, Declaration on Physician Independence and Professional Freedom, European Charter of Patients' Rights, International Code of Medical Ethics, Constitution of Ukraine, Criminal and Civil Codes of Ukraine, Laws of Ukraine «Grounds of Ukrainian Legislation on Health Care» and «About Consumers' Rights Protection», Decree of the President of Ukraine "About doctor's oath», orders of the Ministry of Health of Ukraine, etc.), which regulate legal relations in the field of medical services provision.

The methods of theoretical analysis and synthesis were used while studying the content of legal norms and concepts contained in international legal acts, Criminal and Civil Codes of Ukraine, the Law of Ukraine «Grounds of Ukrainian legislation on health care», in scientific papers by foreign and domestic researchers, in verdicts, decisions and court rulings on cases of violations of patients' rights. The method of systematic analysis was used to determine the content of the human right to health care, the right to consent to medical intervention (application of diagnostic, prevention or treatment methods) and the right to refuse medical intervention and determining ways to implement it in Ukraine.

Formal-legal analysis of international and Ukrainian legislation on health care and patients' rights protection gave an ability to identify the inherent shortcomings and contradictions of legal acts and to formulate proposals to improve legal regulation, in particular, on the need for establishing a regulation on strict compliance with treatment recommendations which are contained in clinical protocols approved on the basis of the principles of evidence-based medicine. By using the comparative-legal method, the experience of certain countries in implementing and exercising the principles of evidence-based medicine was studied. Other separate scientific methods of cognition, in particular formal-logical (for typification of medical errors and their consequences), functional (while identifying the influence of local clinical protocols on process of collecting and an estimation of the facts of non-performance or improper performance of professional duties by medical or pharmaceutical worker, violation of patients' rights), sociological (while analyzing the results of activities by monitoring groups to identify facts of non-performance or improper performance of professional duties by a medical or pharmaceutical worker, assessing the level of latency of such offenses), etc.

\section{REVIEW AND DISCUSSION}

Life and health of every person is the main asset of mankind. Healthy nation problems have not only socio-political but also economic significance. Thus, Belarusian economists have calculated the economic damage caused to the state by the death of a person of working age. In particular, the annual contribution to the GDP of a person of working age is about 10,000 US dollars. If a person dies at an early working age and does not live to retire about $10-15$ years, loss of income of the state is $100000-150000$ US dollars. The direct expected economic losses from mortality in working age are millions of dollars [4]. It should be noted that until 1980, physicians around the world while selecting the meds for the treatment of patients relied solely on their own experience or on the recommendations of the most recognized experts in the field of medicine. Such an approach to doctors' choice of treatment methods has often led to negative and sometimes tragic consequences. As Juan E. Méndez notes, medical professionals today 
receive a comprehensive education that includes the practice and ethics of modern medicine, but blatant violations of physical integrity and human dignity come from the hands of those professionals and "in the name of medicine" worldwide [5].

In 1979, the famous English epidemiologist Archie Cochrane for the first time in the world justified the need to use in practical medicine only those data that could be obtained in the process of properly organized and proven scientific research. He suggested writing scientific medical reviews based on the systematic collection and analysis of facts with regular new data updating [6]. These ideas have found their supporters and since 1980 in the diagnosis and treatment of diseases spread the technology of collection, analysis, synthesis and application of scientific medical information, which allows to make optimal clinical decisions that provide quality medical care to the patient considering its economic efficiency (financial and time spending reduction on patient's treatment). Such scientifically justified medical practice in 1990 at the suggestion of Canadian scientists from McMaster University was called «evidence-based medicine», which involves in everyday medical practice (in diagnosis, treatment and prevention) the usage of medical technologies and drugs, which effectiveness has been proven in pharmacological studies using mathematical estimates of the probability of success and risk [7].

According to M.P. Skakun, evidence-based medicine is a strategic direction of modern medical science and practice, which is based on impeccable scientific information and focused on improving the level of scientific research, significantly improving the diagnosis, prevention, treatment and prognosis of human diseases, optimizing the state health care system [8]. Despite a relatively short period of existence, evidence-based medicine has achieved significant results, which are as follows:

- evidence-based medicine covers the world experience of internal diseases diagnosis and treatment and is based on medical information, the reliability of which is undoubtable. Thus, John R. Buscombe points out that laboratory studies to determine the effectiveness of radionuclide therapy in the treatment of tumors have been carried out for 15 years and only when a positive result is obtained in $80 \%$ of patients, the appropriate treatment protocol was adopted [9];

- evidence-based medicine, as a type of medical practice, differs in the consistent and conscious usage of only those interventions in the patient's treatment, the usefulness of which has been proven in benign studies. It should be noted that due to over-reliance on clinical results published by well-known physicians and medical scholars in various medical publications, physicians may make incorrect diagnostic or therapeutic decisions and thus endanger the health or even life of the patient. Therefore, according to Margaret MacDougall, Helen S. Cameron and Simon R. J. Maxwell, to make a correct diagnosis and to avoid errors in treatment, health professionals should be guided by evidence-based medicine, based on long-term research using a large amount of empirical material [10]; - evidence-based medicine is aimed at releasing medical science and medical practice from outdated and ineffective methods of diagnosis and treatment. Analyzing the negative impact of numerous doctors' errors on patients' health, Canadian medical scientist Allan S. Detsky argues that medical errors have become more common today due to the complexity of treatment methods and to the lack of clinical protocols unification. The evidence-based medicine usage, multidisciplinary approaches, cooperation with patients and the use of electronic systems to support clinical decision-making should facilitate the timely detection and prevention of medical errors in the future [11];

- evidence-based medicine allows to create individual treatment programs for the disease at any level of medical care provision;

- evidence-based medicine ensures the achievement of the maximum effect of treatment with minimal use of pharmaceuticals. According to Hans-IkoHuppertz, the application of effective approaches and avoidance of ineffective medical recommendations will cause the quality of medical services improvement [12];

- evidence-based medicine is aimed at reducing the influence of subjective factors on the choice of criteria for diagnosis and treatment of a particular patient in accordance with the recommended algorithms.

Thus, evidence-based medicine could be defined as the faithfully, accurate and meaningful use of the best results of clinical studies to choose a method of treatment for a particular patient [13]. It is a kind of approach, the concept of a new modern clinical thinking, based on the collection, analysis, generalization and interpretation of information for the choice of methods and treatment recommendations, which are or will be obtained as a result of clinical experiments on human beings [14]. While doing so the development and selection of optimal criteria for diagnosing diseases of patients is a key component of evidence-based medicine, where special attention should be paid to the development of a standardized set of indicators based on the results of clinical testing [15]. Therefore, the inclusion into the pharmacy and medicine educational program of evidence-based information is appropriate and extremely important in the permanent growing role and responsibility of physicians and pharmacists to meet the needs of patients in the use of drugs in compliance with one's rights [16].

In 1992, a world organization, named in honor of Archibald Cochrane - the Cochrane Collaboration, was established. Its primary task is to systematize information for periodicals and analyze the results of research in medical science and treatment practice. Today, doctors, researchers, and representatives of consumer organizations from around the world prepare systematic reviews and analyzes of clinical studies at the research centers of the Cochrane Collaboration. The results of their activities are publicly available in an electronic evidence-based database called The Cochrane Library, which contains systematic 
reviews, abstracts and research in all areas of medicine and healthcare. Summaries of examinations are available free of charge, as well as a self-search on the server is available, which is a significant asset of medicine [17]. In view of the above, we consider it appropriate to join the opinion of scientists and practitioners on the need to open a Ukrainian branch of the Cochrane Collaboration and its' electronic library [18].

The degree of evidence of certain clinical studies is determined jointly by the Cochrane Collaboration, the World Health Organization, the Society for Critical Care Medicine and the British Medical Journal. Guidelines for doctors in the form of certain standards and protocols are created on the basis of reliable scientific evidence.

It should be emphasized that the use in clinical practice of clinical protocols and clinical guidelines as documents containing requirements and recommendations for methods of medical care should be considered as one of the most important ways to implement evidence-based medicine. The main order regulating the introduction of evidence-based medicine in Ukraine is the Order of the Ministry of Healthcare of Ukraine № 751 «On the creation and implementation of medical-technological documents for standardization of medical care of the Ministry of Healthcare of Ukraine» of 28.09.2012. In addition, order of the Ministry of Healthcare of Ukraine № 1422 of December 29,2016 , which allows Ukrainian doctors to use international clinical protocols in their work, came into force. The mentioned protocols are, first of all, a clear algorithm of actions for practicing doctors. The implementation of international protocols would contribute coherence in the provision of medical care to patients at all levels, as well as ensures that each patient receives a high level of medical care.

According to the Law of Ukraine "Grounds of the Legislation of Ukraine on Health Care», a clinical protocol is a unified document that defines the requirements for diagnostic, treatment, prevention and rehabilitation methods of medical care and their sequence. A clinical recommendation, according to the Order of the Ministry of Healthcare of Ukraine № 751 of 28.09.2012, is defined as a document containing systematic provisions on medical and medical-social care, developed using evidence-based medicine methodology on the basis on confirmation of their reliability and credibility, and is aimed at providing assisting the doctor and the patient in making a rational decision in different clinical situations.

There are several types of clinical protocols: 1 ) international clinical protocols; 2 ) unified protocols approved by the Ministry of Healthcare of Ukraine on the basis of guidelines for the various diseases treatment; 3 ) local protocols (routes), which are developed on the basis of unified and approved by the relevant officials (usually these protocols are approved by the Department of Healthcare of the regional state administration and are approved by an order of the chief physician of the health care institution). They could be supplemented by appropriate additions, for example, «Information card of the main actions in the case of anaphylaxis», which further detailed the algorithm of actions of the doctor in the selection and implementation of treatment measures is prescribed; 4) new clinical protocols, which are created according to the initiative of a particular doctor on the basis of international clinical protocols and other guidelines for the treatment of various diseases and approved by the relevant internal order of the health care institution.

The special literature drew attention to certain shortcomings of the existing unified and local clinical protocols and the procedures for their development and approval. In particular, unified clinical protocols may contain trade names of drugs, which lead to lobbying the interests of certain manufacturers of pharmaceutical products. In some cases, unified protocols are developed according on the «personal experience» of the members of the working group and on the outdated, non-evidence base. Unified and local clinical protocols are mainly prepared according to the capabilities of the healthcare system, and not to the needs of patients. It violates the right of patients to access the information about modern treatments methods. Moreover, despite the methodology of development of unified protocols approved by the Order of the Ministry of Healthcare of Ukraine No. 751, which meets European standards, the end result is far from them in practice. Since 2012, only 123 unified protocols have been created in Ukraine, covering a small percentage of diseases. Therefore, the permission to use new clinical protocols really provides access to world standards of almost all diseases treatment, without waiting for the working groups in Ukraine to complete the development of unified protocols [19].

Evidence-based medicine also provides a greater opportunity for the doctor to choose the optimal method of treatment at his/her discretion. Thus, if at the same time there is a unified clinical protocol and a new clinical protocol, then according to the decision by the doctor a new clinical protocol could be applied. In this case, the doctor should explain the differences in treatment protocols and obligatory to obtain the patient's informed consent (in certain situations the decision is made by a legal representative). When a new protocol is used, the doctor is relieved of the obligation to use a unified protocol.

Unified clinical protocols remain mandatory if the health care facility does not approve new clinical protocols or the patient has not given an informed consent. Healthcare institutions have the right to independently select and translate international protocols, with their subsequent approval by the relevant internal order. Such protocols are allowed to be used only in the work of still that particular healthcare institution. While doing so, doctors, other subjects of medical services, regardless of their educational-qualification level and position (paramedic, nurse, etc.) have to access these protocols verifying this fact by the signature and to strictly adhere to their provisions while the medical care provision. According to Michelle Robson and co-authors, healthcare professionals must adhere to clinical protocols and be aware of certain risks when choosing patient treatments. Otherwise, the doctor may face professional disci- 
plinary punishment, prohibition or restriction on medical activities, loss of professional reputation [20].

Contacts with various international institutions and organizations facilitate the process of intensifying the access by medical workers to clinical protocols based on evidence-based medicine. Thus, thanks to the cooperation of the Ministry of Healthcare of Ukraine with the company of the Finnish medical-scientific society Duodecim Medical Publications Ltd., which specializes in integrated solutions in the field of evidence-based medicine, an online platform for primary care physicians was created and introduced. Modern clinical protocols based on evidence-based medicine could be found there and accordingly, it is possible to deepen physicians' professional knowledge [19]. In addition, the protocols approved by the Ministry of Healthcare of Ukraine on the basis of guidelines for the various diseases' treatment are now collected for convenience on the website of the Ukrainian Medical Journal [21]. The NGO «Foundation of Medical Law and Bioethics of Ukraine» also joined the implementation of these ideas [22].

It is also interesting that one of the options for checking the quality of a scientific publication in the field of medicine is its «blind» (anonymous, independent) peer review by three or more specialists in this field. Not only doctors but also patients could check the quality and effectiveness of any treatment methods at the same time. On this issue, Martin Bientzle and co-authors rightly believe that the choice of pharmacological or surgical treatment methods for patients should be made jointly by physicians and patients, which will help the patient to make informed decisions about optimal treatments based on factual data analysis obtained due to the evidence-based medicine measures [23]. Steffen Häfner and co-authors emphasize that physicians should perceive the patient as a person, who makes decision on the way of his/her treatment, and not the one who agrees with the physician's opinion on that issue in advance [24]. A reasonably well way to protect patients' rights has been proposed by US doctors, who have set up an online communication system at three medical centers with patients who have visited doctors and received records in their medical cards describing symptoms, medical diagnosis and treatment suggested. Analysis and summarization of the survey of 1,400 patients allowed to find that in $25 \%$ of cases, medical records contained significant inaccuracies that could potentially lead to a deterioration in patients' health status. The most common types of potential inaccuracies included a description of symptoms (21\%), previous medical problems (21\%), prescribed meds (18\%), and important additional information about chronic diseases and patient health conditions (15\%). Inaccuracies in the medical records were subsequently corrected and medical appointments were adjusted. The authors of the idea believe that the cooperation of doctors with patients will help protect their rights and increase the effectiveness of treatment [25]. In other words, evidence-based medicine helps to establish a dialogue between doctors and patients who, according to Dainius Puras, should participate in decision-making regarding future diagnostic and therapeutic interventions [26].

Thus, in modern conditions, due to global informatization, patients' rights are expanding. Healthcare pro- fessionals are no longer the only source of information about the symptoms and diagnosis of diseases, methods and protocols for their treatment, modern medicines and medical equipment, treatment options for certain diseases in medical clinics around the world, possible risks and causes of negative results of healthcare provision. That is why medical and pharmaceutical workers generally try not to violate the rights of the patient, as they are constantly under close control by the state, society, law enforcement bodies, patients themselves and their relatives.

In the context of the considered issues, the statement that clinical protocols should be developed and approved only on the basis of unambiguous medical information based on the results of scientific research and clinical observations, should be axiomatic. It also applies to the emergence of new, unknown diseases, which are of a mass character, having intensive for widespreading and require immediate response by the relevant government agencies. Coronavirus disease COVID-19 could be considered as such. In the context of the COVID-19 pandemic conditions, pharmacological studies on the effectiveness of treatment of this disease based on the approaches of evidence-based medicine have become especially relevant. Clinical treatment protocols for COVID-19 treatment are constantly changing and supplemented. In order to achieve the most coordinated possible approach to obtaining the results of medicines testing in the European Union, the document "Guidance on the management of clinical trials during the covid-19 (coronavirus) pandemic» was published [27]. In addition, most countries around the world are conducting research to develop protocols for early diagnosis of this disease, establishing the stages of the disease and the degree of risk to the patient's life. Depending on the presence of associated comorbidities, treatment methods and their effectiveness are analyzed. Thus, in the United Kingdom, a group of scientists analyzed the effectiveness of treatment of 22,361 patients for the period from May 21, 2020 to June 29, 2020, who were observed by doctors at least for four weeks. The results of these studies were immediately published in the public access on the Internet [28]. That is why rather hasty statements about the completion of vaccine development from COVID-19 (as one that has not been properly researched) cause some concern.

The introduction of evidence-based clinical protocols is intended not only to optimize the provision of medical services, but also to facilitate the collection of evidence of the guilt or innocence of doctors in criminal and civil proceedings. At the same time, the protocols themselves should be considered as sources of law, as a kind of guide in clarifying and assessing the facts of non-performance or improper performance of professional duties by a medical or pharmaceutical worker, violation of patients' rights, as well as measures for doctor's legal protection.

It should be noted that there are different approaches to resolving conflicts that arise between doctors and patients in world practice. Thus, in the United States, the United Kingdom, Canada, New Zealand, South African Republic and other countries, disputes arising from harm to the life 
and health of patients while performing of their professional duties by healthcare workers are mainly resolved by methods of civil law regulation. Criminal measures are applied only in special cases. Whereas in Japan, Saudi Arabia, Belarus, Russia, Kazakhstan, Armenia, and Latvia, medical workers are primarily criminally liable for the results of their professional activities under general rules that provide for liability for harm to life and health. In particular, according the Criminal code of the Russian Federation it is possible to bring the doctor to criminal responsibility under several articles: Art. 109 (causing death by negligence), Art. 118 (causing grievous bodily harm through negligence), Art. 124 (non-providing care to the patient), Art. 235 (illegal medical or pharmaceutical activities) [29]. According to the data by Investigative Committee of Russia, only $10 \%$ of criminal cases investigated against doctors go to court, in $90 \%$ of cases investigators prove their innocence. Only those doctors who have committed gross violations of treatment standards and protocols are prosecuted in Russia [30].

According to the results of the analysis of the statistics of the pre-trial investigation bodies (see Table 1), it was established that the corpus delicti provided for in Art. 140 of the Criminal Code of Ukraine (Improper performance of professional duties by a medical or pharmaceutical worker), is the most widespread among crimes against life and health of a person, the subjects of which are medical workers. Thus, from January 2016 to September 2020, 3182 such criminal offenses were registered. At the same time, only in $11(0,35 \%)$ criminal proceedings medical workers were given a notice of suspicion, and only $8(0,25 \%)$ proceedings were sent to court with prosecuting acts. At the same time, a significant part of criminal proceedings (1608 or $50,53 \%$ ) was subsequently closed by the pre-trial investigation bodies, primarily due to the absence of a criminal offense or the absence of a corpus delicti.

For the same period under the Article 141 «Violation of the patient's rights», the suspicion was not handed over to any doctor, 3 proceedings were closed, and no decision was made at all on the other two.

In view of the above, among the main problems of the investigation of «medical crimes» there are the following: - the lack of investigator's medical knowledge, and hence the need to involve relevant experts, medical and pharmaceutical workers as specialists in the conduct of investigative (searching) actions;

- the lack of proper experience and practice of investigating criminal offenses of this category. For example, out of 128 interviewed prosecutors, only $31(26,3 \%)$ indicated that they had faced with proceedings concerning the improper performance of professional duties by a medical or pharmaceutical worker in practice;

- the need to quickly obtain the decision of the investigating judge on temporary access to things and medical documents, which leads to a situation where due to delays in obtaining such a decision, the medical institution manages to destroy the evidence in practice;

- mutual help of medical workers, which consists in evidence destroying (medical card data, test results, etc.);
- the desire to attribute any unsuccessful manipulation or surgical intervention that led to serious consequences solely to a medical error;

- covering up by the heads of medical institutions of their subordinates, active opposition to the investigation;

- difficulty in distinguishing negligence from accident, medical error and justified medical risk.

In turn, the analysis of case law shows that the courts are guided primarily by the provisions of clinical protocols in making a decision on the guilt of a particular medical worker $[32 ; 33 ; 34]$. Clinical protocols are also the basis for acquittals of doctors. Thus, during the court hearing it was found out that the doctor had no reason to believe that the patient had a disorder in the body regarding thrombosis, which later led to her death. He made recommendations for the treatment of the patient with the exception of certain laboratory tests, the absence of which could not affect the course of the disease [35].

Clinical protocols as sources of evidentiary information are also used by courts of civil jurisdiction while clarifying the circumstances of providing the appropriate level of medical care and making decisions on compensation for material and moral damage caused by deteriorating health $[36$; 37; 38]. At the same time, well-founded court decisions, which not only state the fact of existing errors in the diagnosis and treatment of the disease, but also determine the amount of compensation to the patient, emphasizes Maya Peled-Raz, contribute to the realization of one's rights to appropriate medical care [39]. National human rights organizations also pay attention to this fact in their reports [40].

\section{CONCLUSIONS}

Appropriate medical care is the provision of medical care by a healthcare professional in accordance with current clinical protocols and guidelines based on evidence-based medicine, considering the clinical situation and respecting patients' rights, especially - with the informed consent of the patient on medical intervention.

The introduction into medical practice of the principles and approaches of evidence-based medicine should be seen as a significant step towards reforming the medical field, improving the medical services provision, and the patients' rights protection. Created on the basis of medical information, the reliability of which is undoubtable, clinical protocols are rightly considered as an effective tool for improving the efficiency of medical professionals. In addition, in court-investigative practice, they serve as an informative means of proving the guilt or innocence of medical workers for non-performance or improper performance of their professional duties.

While creating guidelines that serve as the basis for the development and approval of clinical protocols, it is necessary to use those methods of diagnosis and treatment, the effectiveness of which has been proven in clinical studies in hundreds of thousands of patients.

To implement the rights of the patient in the diagnosis and treatment of diseases, it is necessary to regulate a set of such measures: 
Table 1. Information on the results of criminal proceedings in Ukraine by article 140 of the Criminal Code of Ukraine «Improper performance of professional duties by a medical or pharmaceutical worker» (from January 2016 to September 2020) [31].

\begin{tabular}{cccccc}
\hline Year & $\begin{array}{c}\text { Criminal offenses } \\
\text { registered }\end{array}$ & $\begin{array}{c}\text { Notices of } \\
\text { suspicion } \\
\text { given }\end{array}$ & $\begin{array}{c}\text { Criminal } \\
\text { proceedings sent } \\
\text { to court }\end{array}$ & $\begin{array}{c}\text { Criminal offences } \\
\text { where proceedings } \\
\text { were closed }\end{array}$ & $\begin{array}{c}\text { Criminal offences without } \\
\text { any decision to the end of } \\
\text { the review period }\end{array}$ \\
\hline 2016 & $\underline{642}$ & $\underline{2}(0,31 \%)$ & $\underline{1}(0,16 \%)$ & $\underline{208}(32,39 \%)$ & $\underline{641}(99,84 \%)$ \\
\hline 2017 & $\underline{725}$ & $\underline{2}(0,27 \%)$ & $\underline{2}(0,27 \%)$ & $\underline{234}(32,27 \%)$ & $\underline{723}(99,72 \%)$ \\
\hline 2018 & $\underline{655}$ & $\underline{3}(0,45 \%)$ & $\underline{3}(0,45 \%)$ & $\underline{251}(38,32 \%)$ & $\underline{652}(99,54 \%)$ \\
\hline 2019 & $\underline{669}$ & $\underline{2}(0,28 \%)$ & $\underline{1}(0,15 \%)$ & $\underline{296}(44,24 \%)$ & $\underline{668}(99,85 \%)$ \\
\hline $\begin{array}{c}\text { January- } \\
\text { September } 2020\end{array}$ & 492 & $2(0,41 \%)$ & $1(0,20 \%)$ & $203(41,26 \%)$ & $490(99,59 \%)$
\end{tabular}

Table 2. Information on the results of criminal proceedings in Ukraine under Article 141 of the Criminal Code of Ukraine «Violation of the patient's rights» (from January 2016 to September 2020) [31].

\begin{tabular}{ccccc}
\hline Year & $\begin{array}{c}\text { Criminal offences in } \\
\text { the review period } \\
\text { included }\end{array}$ & $\begin{array}{c}\text { Criminal offences where } \\
\text { notices of suspicion given }\end{array}$ & $\begin{array}{c}\text { Criminal offences } \\
\text { where proceedings } \\
\text { were closed }\end{array}$ & $\begin{array}{c}\text { Criminal offences without } \\
\text { any decision to the end of the } \\
\text { review period }\end{array}$ \\
\hline 2016 & $\underline{1}$ & $\underline{0}$ & $\underline{1}(100 \%)$ & 0 \\
\hline 2017 & $\underline{0}$ & $\underline{0}$ & $\underline{1}(100 \%)$ & 0 \\
\hline 2018 & $\underline{0}$ & $\underline{0}$ & $\underline{1}(100 \%)$ & $1(100 \%)$ \\
\hline 2019 & 1 & 0 & $1(100 \%)$ \\
\hline $\begin{array}{c}\text { January- } \\
\text { September } \\
2020\end{array}$ & 1 & 0 & 0 & 1 \\
\hline
\end{tabular}

1. To include in the curricula of pharmacy and medicine such disciplines as "Evidence-based medicine» and «Medical worker's and patient's rights».

2. Oblige the physician to explain to the patient or his/her representative the differences of treatment protocols, provide information to patients about official sources that contain information on unified and updated protocols on treatment and diagnosing of certain diseases, to obtain informed consent from the patient (or his/her representative) about a specific guideline.

3. Recognize guidelines as sources of law in criminal and civil proceedings as a kind of benchmarks in clarifying and assessing the facts of non-performance or improper performance of professional duties by a medical or pharmaceutical worker, violation of patients' rights, as well as means of doctor's legal protection etc.

\section{REFERENCES}

1. European Court of Human Rights. ECHR 2014/8 Case of Valeriy Fuklev v. Ukraine, 16 January 2014, no. 6318/03 (Fifth section). European Journal of Health Law, 01 Jun 2014, 21(3):297-300. doi: 10.1163/1571809312341318.

2. Case of Petrova v. Latvia (Application no. 605/05). Strasbourg, 24 June 2014. Available from: https://hudoc.echr.coe.int/ eng\#\{\%22itemid\%22:[\%22001-144997\%22]\} [reviewed 2020.08.23].

3. Case of Bataliny v. Russia (Application no. 10060/07). Strasbourg, 23 July 2015. Available from: http://hudoc.echr.coe.int/eng?i=001-156246 [reviewed 2020.08.22].
4. Elystratova M.Vrach y patsyent: balans prav y otvetstvennosty. [Doctor and patient: balance of right sandresponsibility]. Healthcare. №3.2019. Available from:http://www.zdrav.by/kruglyj-stol/2830/[reviewed 2020.09.12] (Ru).

5. Juan E. Méndez. Report of the Special Rapporteur on torture. United Nations General Assembly. Human Rights Council. Twenty-second session. A/HRC/22/53.1 Feb 2013. Available from: http://www.ohchr. org/Documents/HRBodies/HRCouncil/RegularSession/Session22/A. HRC.22.53_English.pdf [reviewed 2020.08.23].

6. Yurev K. L., Loganovskiy K. N. Dokazatelnayameditsina. Kokranovskoesotrudnichestvo [Evidence-based medicine.Cochrane Collaboration].Ukrainian medical journal.2000; 6(20):6-15. Available from: https://www.researchgate.net/profile/Konstantin_Loganovsky/ publication/281711508_Evidence-based_medicine_Cochrane_ collaboration/links/55f54a6f08ae7a10cf890d28/Evidence-basedmedicine-Cochrane-collaboration.pdf [reviewed 2020.08.12] (Ru).

7. Dokazova medytsyna. Farmatsevtychna entsyklopediia [Evidencebased medicine. Pharmaceutical encyclopedia]. National pharmacist. university, 2019. Available from: https://www.pharmencyclopedia. com.ua/article/2565/dokazova-medicina [reviewed 2020.08.11] (Ua).

8. Skakun M. P. Osnovy dokazovoi medytsyny [Fundamentals of evidencebased medicine]. Ternopil: Ukrmedknyha, 2005. 244 p. (Ua).

9. JohnR. Buscombe. Evidence Base for the Use of PRRT. Seminars in nuclear medicine.Vol. 50(5): 99-404. doi: 10.1053/j.semnuclmed.2020.04.001.

10. MacDougall, M., Cameron, H.S. \& Maxwell, S.R.J. Medical graduate views on statistical learning needs for clinical practice: a comprehensive survey. BMC Medical educatio. Dec 31 2020; Vol. 20(1). Available from: https://bmcmededuc.biomedcentral.com/articles/10.1186/s12909019-1842-1 [reviewed 2020.08.11].

11. Detsky AS. Finding Out Your Doctor Made a Mistake. J Gen Intern Med. 2020 Sep 23. doi: 10.1007/s11606-020-06228-9. 
12. Hans-lko Huppertz. Evidence-based control of Pediculosiscapitis and secondary prevention Statement of the Committee for Infectious Diseases and Vaccinations of the German Academy for Pediatrics and Adolescent Medicine. Monatsschrift Kinderheilkunde. Aug 2020. Available from: https://link.springer.com/article/10.1007/s00112-02000987-9 [reviewed 2020.08.11].

13. Dokazova medytsyna: yak pryimaty klinichni ta upravlinski rishennia [Evidence-based medicine: howtomake clinical and management decisions]. Availablefrom: https://www.medsprava. com.ua/article/572-dokazova-meditsina-na-praktits [reviewed 2020.08.09] (Ua).

14. Linchevskyi 0 . Nadvysokatsina. Chomu vazhlyva dokazova medytsyna [Extreme lyhigh price. Why evidence-based medicine is important]. UkrainianTruth, December 26, 2016. Available from: https://life.pravda.com.ua/health/2016/12/26/221910 [reviewed 2020.08.13] (Ua).

15. Timothy R. Nicholson, Alan Carson, Mark J. Edwards. Outcome Measures for Functional Neurological Disorder: A Review of the Theoretical Complexities. Journal of neuropsychiatry and clinical neurosciences. Vol. 32(1): 33-42. doi: 10.1176/appi.neuropsych. 19060128.

16. Chandran, V. P., Khan, S., Kulyadi, G. P., Devi, E. S., \&Thunga, G. Evidence based medicine and pharmacy curriculum: an insight into Indian perspective. Bangladesh Journal of Medical Science, 2020; 19(4), 603-608. doi:10.3329/bjms.v19i4.46613.

17. Cochrane Library: Cochrane Reviews. Available from: https://www. cochranelibrary.com [reviewed 2020.08.11].

18. Resursy z dokazovoi medytsyny [Evidence-based medicine resources]. Available from: http://libr.knmu.edu.ua/index.php/resursi-zdokazovoji-meditsini [reviewed 2020.08.12] (Ua).

19. Linchevskyi 0.0 lain-platformy z protokolamy na zasadakh dokazovoi medytsyny [Online platforms with protocols based on evidence-based medicine]. Available from: https://moz.gov.ua/article/protocols/ onlajn-platforma-z-protokolami-na-zasadah-dokazovoi-medicini [reviewed 2020.08.13] (Ua).

20. Robson M, Maskill J, Brookbanks W. Doctors Are Aggrieved-Should They Be? Gross Negligence Manslaughter and the Culpable Doctor. The Journal of Criminal Law. 2020;84(4):312-340. doi:10.1177/0022018320946498.

21. Sait Ukrainskoho medychnoho chasopysu [Website of the Ukrainian medical journal]. Available from: https://www.umj.com.ua/standartyi-protokoly [reviewed 2020.08.19] (Ua).

22. Sait hromadskoi orhanizatsii «Fundatsiia medychnoho prava ta bioetyky Ukrainy» [Website of the public organization «Foundation of medical law and bioethics of Ukraines]. Available from: http://www. medicallaw.org.ua/. [reviewed 2020.08.15] (Ua).

23. Bientzle M, Kimmerle J, Eggeling M. et al.Evidence-Based Decision Aid for Patients With Parkinson Disease: Protocol for Interview Study, Online Survey, and Two Randomized Controlled Trials. Jmir research protocols. Jul 2020; 9(7). doi: 10.2196 / 17482.

24. Häfner Set al.The Patient - Partner in Medical Decision Making. Balint Journal 2020; 21(03): 86-90. doi: 10.1055/a-1248-7923.

25. Bourgeois FC, Fossa A, Gerard M, Davis ME, Taylor YJ, Connor CD, Vaden T, McWilliams A, Spencer MD, Folcarelli P, Bell SK. A patient and family reporting system for perceived ambulatory note mistakes: experience at 3 U.S. healthcare centers. J Am Med Inform Assoc. 2019 Dec 1;26(12):1566-1573. doi: 10.1093/jamia/ocz142. PMID: 31504576.

26. Püras, D. Human rights and the practice of medicine.Public Health Rev 38, 9 (2017). doi: 10.1186/s40985-017-0054-7.
27. Guidance on the management of clinical trials during the covid-19 (coronavirus) pandemic.Version 3.28/04/2020. Commission européenne/Europese Commissie, 1049 Bruxelles/Brussel. Available from: https://ec.europa.eu/health/sites/health/files/files/eudralex/ vol-10/guidanceclinicaltrials_covid19_en.pdf [reviewed 2020.08.19].

28. Knight Stephen R, Ho Antonia, Pius Riinu, Buchan lain, Carson Gail, Drake Thomas $\mathrm{M}$ et al. Risk stratification of patients admitted to hospital with covid-19 using the ISARIC WHO Clinical Characterisation Protocol: development and validation of the 4C Mortality Score. BMJ 2020;370:m3339.doi: doi:10.1136/bmj.m3339.

29. Ugolovnyj kodeks Rossijskoj Federacii [Criminal Code of the Russian Federation]. Editionfrom 31.07.2020. Available from: https://rulaws. ru/uk/ [reviewed 2020.09.20] (Ru).

30. Kozlova N. Pravonaoshibku [The right to make mistakes]. Rossijskaya gazeta. № 158(7621). 22.07.2018. Available from: https://rg.ru/2018/07/22/sledovateli-i-mediki-prokommentirovaliizmeneniia-v-uk-dlia-vrachej.html [reviewed 2020.09.22] (Ru).

31. Yedyni zvity pro kryminalni pravoporushennia z sichnia 2016 r. po veresen $2020 \mathrm{r}$. [Unified reports on criminal offenses from January 2016 to September 2020]. Ofitsiinyi sait Heneralnoi prokuratury Ukrainy. Available from: https://old.gp.gov.ua/ua/stst2011.html?dir_ id $=112661 \&$ libid $=100820 \#$ [reviewed 2020.09.23] (Ua).

32. Vyrok Stryiskoho miskraionnoho sudu Lvivskoi oblasti vid 24 kvitnia 2019 r. u spravi № $456 / 310 / 18$ [The verdict ofthe Stryj] City District Court of the Lviv Region of April 24, 2019 in the case №456/310/18]. Available from: http:// reyestr.court.gov.ua/Review/81410675 [reviewed 2020.08.17] (Ua).

33. VyrokVinnytskoho raionnoho sudu Vinnytskoi oblasti vid 21 sichnia 2019 r. u spravi № 128/998/18 [The verdict of the Vinnytsia District Court of the Vinnytsia Region of January 21, 2019 in the case №128/998/18]. Available from: http://reyestr.court.gov.ua/Review/79281813 [reviewed 2020.08.20] (Ua).

34. Vyrok Krasnoarmiiskoho miskraionnoho sudu Donetskoi oblasti vid 27 hrudnia 2018 r. u spravi № 226/627/17 [The verdict of the Red Army City District Court of Donetsk region of December 27, 2018 in the case №226/627/17]. Available from: http://reyestr.court.gov.ua/ Review/79281813 [reviewed 2020.08.18] (Ua).

35. Vyrok Berezanskoho miskoho sudu Kyivskoi oblasti vid 25 lystopada 2013 r. u spravi № 1002/1-2/12 [The verdict of the Berezan City Courtof Kyiv Region of November 25, 2013 in the case №1002/1-2/12]. Available from: http://reyestr.court.gov.ua/Review/35490714 [reviewed 2020.08.17] (Ua).

36. Postanova Kasatsiinoho tsyvilnoho sudu Verkhovnoho Sudu vid 27.02.2019 roku u spravi № 755/2545/15-ц [Resolution of the Civil Court of Cassation of the Supreme Court of February 27, 2019 in the case №755/2545/15-c]. Available from: http://reyestr.court.gov.ua/ Review/81020404 [reviewed 2020.08.19] (Ua).

37. Rishennia apeliatsiinoho sudu Zaporizkoi oblasti vid 23.03.2017 roku u spravi № 315/1194/15-ц [The decision of the Court of Appeal of Zaporozhye region from 23.03.2017 in the case №315/1194/15c]. Available from: http://reyestr.court.gov.ua/Review/65617895 [reviewed 2020.08.19] (Ua).

38. Rishennia Dniprovskoho raionnoho sudu m. Kyievavid 10.01.2019 r. u spravi № 755/6312/16-ц [Decision of the Dniprovsky District Court of Kyiv of January 10, 2019 in the case №755/6312/16-c]. Availablefrom: http:// reyestr.court.gov.ua/Review/79216095 [reviewed 2020.08.19] (Ua).

39. Peled-Raz, M. Human rights in patient care and publichealth-a common ground. Public Health Reviews 2017; 38: 29. doi:10.1186/s40985-0170075-2. 
40. Sudovyi zakhyst prava na okhoronu zdorovia. Prava liudyny v Ukraini. Uzahalnena dopovid pravozakhysnykh orhanizatsii [Judicial protection of the right to healthcare. Human rights in Ukraine. Summary report of human rights organizations]. 21.04.2014. Available from: http://khpg. org/index.php?id=1398059942 [reviewed 2020.08.13] (Ua).

\section{ORCID and contributionship:}

Vladimir A. Zhuravel: 0000-0001-8256-4333 A, B, D, E, F

Galina K. Avdeeva: 0000-0003-4712-728X A, B, C, D, E

Mykyta O. Sokolenko: 0000-0002-0302-162X ${ }^{B}$

\section{Conflict of interest:}

The Authors declare no conflict of interest.

\section{CORRESPONDING AUTHOR}

\section{Galina K. Avdeeva}

Academican Stashis Scientific Research Institute for the Study of Crime Problems of National Academy Legal Sciences of Ukraine, Kharkiv,Ukraine

tel: +380677800577

e-mail:gkavdeeva@gmail.com

Received: 29.08 .2020

Accepted: 26.11.2020

A - Work concept and design, B - Data collection and analysis, C - Responsibility for statistical analysis, D - Writing the article, $\mathbf{E}$-Critical review, $\mathbf{F}$ - Final approval of the article 